\title{
Somatic cell count and type of intramammary infection impacts fertility from in vitro produced embryo transfer
}

\author{
L.F.S.P. Barbosa ${ }^{a}$, W.V.C. Oliveira ${ }^{a}$, M.H.C. Pereira ${ }^{a}$, M.B. Moreira ${ }^{b}$, C.G.C. Vasconcelos ${ }^{\text {c }}$, \\ B.F. Silper ${ }^{\text {d, R.L.A. Cerri }}{ }^{\text {d }}$, J.L.M. Vasconcelos ${ }^{\text {a, * }}$ \\ a Department of Animal Production, São Paulo State University, Botucatu, 18168-000, Brazil \\ ${ }^{\mathrm{b}}$ Rehagro, Belo Horizonte, 30310-300, Brazil \\ c Laboratório VidaVet, Botucatu, 18618-000, Brazil \\ ${ }^{\mathrm{d}}$ Applied Animal Biology, Faculty of Land and Food Systems, University of British Columbia, Vancouver, V6T 1Z4, Canada
}

\section{A R T I C L E I N F O}

\section{Article history:}

Received 11 July 2017

Received in revised form

11 December 2017

Accepted 11 December 2017

Available online 16 December 2017

\section{Keywords:}

Embryo transfer

Fertility

Intramammary infection

Mastitis

Somatic cell count

\begin{abstract}
A B S T R A C T
The objective of this study was to assess the impact of mastitis-causing bacteria and somatic cell count (SCC) on pregnancy per embryo transfer (P/ET) in Holstein-Gir crossbred (Girolando) lactating dairy cows. Cows $(n=1397)$ were subjected to a timed-embryo transfer protocol. Milk samples were collected two days before embryo transfer for SCC and bacteriological culture analyses. Pregnancy diagnosis was performed on days 31 and 66 after timed-embryo transfer. The animals were grouped according to the National Mastitis Council recommendations: Gram-positive environmental $(\mathbf{E V}+)$, Gram-negative environmental (EV-), Gram-positive contagious (C+), coagulase-negative staphylococci (CNS) and control (no bacterial growth). Additional analysis was made by categorizing bacteria based on degree of pathogenicity (Major or Minor). Bacterial growth reduced P/ET $(\mathrm{P}<.01)$ at both 31 and 66 days of gestation. The $\mathrm{P} / \mathrm{ET}$ was lower $(\mathrm{P}<.05)$ at 31 days in EV- $(30.1 \%)$ and $\mathrm{EV}+(29.9 \%)$ groups and tended $(\mathrm{P}=.09)$ to be lower in the $\mathrm{C}+$ group (36.6\%) than the control group (44.0\%). The P/ET from the Major group at 31 days of gestation was lower $(P=.03)$ compared with the Minor and control groups (32.1 vs 41.1 vs $43.2 \%$, respectively). Cows with $\mathrm{SCC}>400,000$ cells $/ \mathrm{mL}$ had lower $\mathrm{P} / \mathrm{ET}(\mathrm{P}<.01)$ than animals with SCC $<200,000$ cells $/ \mathrm{mL}$ at both 31 (30.4\% vs $40.8 \%$ ) and 66 days (24.7\% vs $32.2 \%)$ of gestation. Pregnancy loss was not different between bacterial isolates and SCC categories. Elevated SCC significantly reduced P/ $\mathrm{ET}$, whereas environmental agents and those with Major pathogenicity yielded the greatest reduction in P/ET.
\end{abstract}

(C) 2017 Elsevier Inc. All rights reserved.

\section{Introduction}

Several studies have described reduced reproductive efficiency in high-producing ( $40 \mathrm{~kg} / \mathrm{d})$ dairy cows fed TMR, typical of the US and Canada, as well as in cows with lower production $(\sim 20 \mathrm{~kg} / \mathrm{d})$ managed in pasture-based systems, typical of New Zealand [1,2]. One of the possible causes for the lower reproductive efficiency in lactating animals is the high prevalence of infectious diseases, such as infectious bovine rhinotracheitis, bovine viral diarrhea and mastitis [3-6]. The intensification of milk production systems increased the risk of intramammary infection and uterine diseases

\footnotetext{
* Corresponding author. Department of Animal Production, Faculty of Veterinary Medicine and Animal Science, Sao Paulo State University, Brazil.

E-mail address: vasconcelos@fmvz.unesp.br (J.L.M. Vasconcelos).
}

[7,8], as these two health disorders are considered risk factors for reduced fertility in dairy cows [4,9] and highly prevalent in dairy herds.

Mastitis is one of the most common infectious diseases in dairy herds, affecting 50 to 70 cases per 100 cows/year [10]. Smith and Hogan [11] have estimated the cost of mastitis to be an around 2 billion dollars per year in the United States, which represents approximately $11 \%$ of the total milk production revenue. The monitoring of intramammary infection is critical to maintain milk quality and udder health [12]. There are several mastitis' diagnostic methods but microbiological culture of milk samples is still considered the gold standard [13]. However, bacterial culture is generally expensive and time-consuming to be routinely used [12]. Thus, individual somatic cell count (SCC) is widely used to monitor udder health by dairy farmers [14] and to establish premiums and penalties by milk processors. 
The relationship between intramammary infection and decrease in reproductive performance has been reported by several studies [5,15,16]. Even in its subclinical form, mastitis can be associated with reduced fertility [17]. Schrick et al. [3] reported that animals with clinical or subclinical mastitis showed greater interval from calving to first AI, and increased days open and services per conception compared with healthy animals. Moore et al. [18] also reported the importance of subclinical mastitis; cows with SCC greater than 300,000 cells/mL before AI were 2.4 times more likely to lose gestation between Day 28 and Day 40 than cows with SCC below that threshold (30.0\% vs. $12.5 \%$ ). According to Philpot and Nickerson [19] for each clinical case of mastitis there are between 15 and 40 subclinical cases, which reinforces the potential for udder health monitoring tools and data analysis to improve reproduction efficiency.

The mechanisms by which subclinical mastitis affect fertility of dairy cows are not well elucidated. Possible factors described are: ovulation failure and reduced production of 17 $\beta$-estradiol [20], lower estrous expression [21], increased prostaglandin F2 $\alpha$ synthesis [4], increased body temperature [22] and release of systemic lipopolysaccharide and nitric oxide that can potentially affect the oocyte and embryo development [23]. The current study was conducted with cows subjected to timed-embryo transfer. The use of $7 \mathrm{~d}$ old embryos that have bypassed some of the above mentioned critical periods, such as oocyte development and early embryonic development [24,25], could provide important information regarding the relative importance of type of bacteria and SCC solely on the uterine environment and embryonic development.

The main objective of this study was to assess the impact of bacteria isolates that cause mastitis and of SCC categories during the timed-embryo transfer protocol on pregnancy per embryo transfer $(\mathbf{P} / \mathbf{E T})$ in lactating dairy cows. We hypothesized that P/ET will be most negatively affected by subclinical inflammation associated with a) infection from gram negative bacteria, b) infection from bacteria with major degree of pathogenicity and c) greater SCC.

\section{Material and methods}

\subsection{Animals and facilities}

This study was conducted in a single commercial dairy herd in the southwestern region of the state of Minas Gerais, Brazil. A total of 1397 Holstein x Gir crossbred cows (Girolando) were enrolled. The average days in milk of cows enrolled in the experiment was $125.9 \pm 6.2$ and milk production averaged $19.2 \pm 0.7 \mathrm{~kg} / \mathrm{cow} /$ day. The herd was managed in a semi-confinement system, in which cows had access to a Panicum maximum (cultivar Mombasa) pasture and a TMR based on corn silage, ground corn and soybean meal in feed bunks. The cows were fed to match or exceed the nutritional requirements for milk production of $25 \mathrm{~kg} /$ day [26]. Milking was performed twice daily and mastitis control practices were executed. In short, the farm personnel performed fore stripping in a strip cup to check for abnormal milk (clinical mastitis), pre-dipping with an iodine solution, drying teats with disposable paper towel and post-dipping. Dry-cow therapy and treatment of clinical cases were also part of the mastitis control program. Two milk samples were collected from each cow two days before embryo transfer (Fig. 1) for microbiological culture and SCC measurements. Milk production was recorded on the same day.

All cows with over 40 days in milk had their reproductive tracts evaluated by transrectal ultrasonography (Mindray - 2200VET DP; Shenzhen Mindray Bio-Medical Electronics CO., Shenzhen, China) and those without visible pathology in the uterus and ovaries were subjected to a timed-embryo transfer protocol (Fig. 1). Cows received an intravaginal device containing progesterone $\left(\mathrm{CIDR}^{\circledR}\right.$ $1.9 \mathrm{mg}$, Zoetis, SP, Brazil) and an injection of $2 \mathrm{mg}$ of estradiol benzoate i.m. ( $2 \mathrm{~mL}$ Estrogin ${ }^{\circledR}$, Farmavet, SP, Brazil) on $\mathrm{d}-11$. On $\mathrm{d}-4$, cows received $25 \mathrm{mg}$ of dinoprost thrometamine i.m. ( $5 \mathrm{~mL}$ Lutalyse $^{\circledR}$, Zoetis, SP, Brazil), Two days later, the CIDR inserts were removed and cows received $1 \mathrm{mg}$ of estradiol cypionate i.m. $(0.5 \mathrm{~mL}$ $\mathrm{ECP}^{\circledR}$, Zoetis, SP, Brazil). On day 7, all cows had their ovaries scanned by ultrasound and only cows with a visible corpus luteum received an embryo that was transferred to the uterine horn ipsilateral to the corpus luteum. The transferred embryos were produced by in vitro fertilization technique and were classified according to the recommendations by Mapletoft [27]. Only grade 1 embryos (best quality) were then transferred as described by Pereira et al. [28].

\subsection{Collection of samples for microbiological culture and SCC}

For the microbiological culture sample collection, teats were disinfected by pre-dipping, dried with paper towel, and further cleaned with a gauze embedded with $70 \%$ ethanol. The first three milk streams from each teat were discarded and a composite sample from all four quarters was collected into a sterile tube. Samples were placed on ice immediately after collection. Samples were then frozen and shipped to a private laboratory for subsequent culture and analyses (VidaVet, Botucatu, SP, Brazil). The milk samples for SCC were collected in vials containing 2-bromo-2nitropropane-1-3-diol and analyzed by flow cytometry (Somacount 300, Bentley, Chaska, MN).

\subsection{Microbiological culture}

Milk samples $(100 \mu \mathrm{L})$ were plated on agar medium supplemented with sheep blood (10\%) defibrinated and in MacConkey agar medium. The samples were incubated aerobically at $37^{\circ} \mathrm{C}$ for 24-48 h. The colonies were subjected to biochemical and bacterial differentiation tests. The readings of the plates were conducted at 24 and $48 \mathrm{~h}$ after plating with the description of the colony macromorphology. The micro-morphology was carried out using the slide smear method and stained by the Gram technique. The microbiological identification was based on morphological, biochemical and staining characteristics according to Quinn et al. [29]. Cows were removed from the study if more than one bacteria from different groups were isolated in the culture $(n=36)$. Samples yielding more than two different bacterial species were considered to be contaminated and also removed from statistical analysis $(n=10)$.

\subsection{Bacterial classification}

After microbial identification, the animals were grouped into 5 groups as recommended by the National Mastitis Council: Control (No bacterial isolation), coagulase negative staphylococci (CNS), contagious gram positive: $(\mathbf{C}+$; Corynebacterium bovis, Staphylococcus aureus, Streptococcus agalactiae), environmental gram positive (EV+; Bacillus spp., Enterococcus spp., Micrococcus spp., Streptococcus spp.), environmental gram negative: (EV-; Citrobacter freundii Coliformes, Enterobacter spp., Klebsiella spp.).

The cows were also divided according to the pathogenicity of the isolated agent as suggested by Schepers et al. [30] and were: Control (No bacterial isolation), Major agents (Staphylococcus aureus, Streptococcus agalactiae, Bacillus spp., Enterococcus spp., Micrococcus spp., Streptococcus spp., Citrobacter freundii, Escherichia coli, Pseudomonas spp, Enterobacter spp., Klebsiella spp), and Minor Agents (CNS and Corynebacterium bovis). 


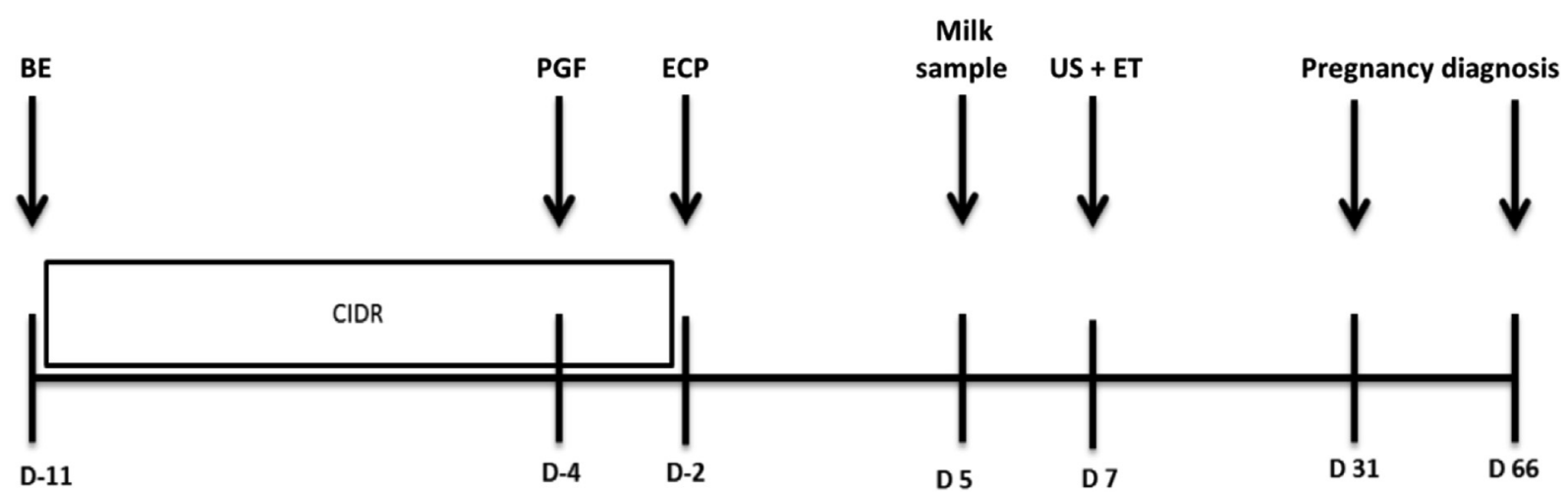

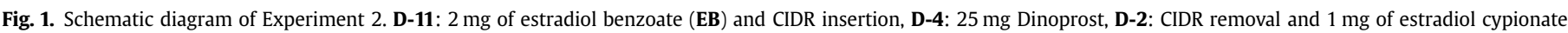

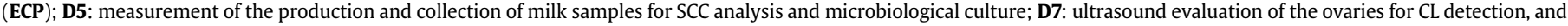
ET in cows with CL; D31: first pregnancy diagnosis; D66: second pregnancy diagnosis.

\subsection{Pregnancy diagnosis}

Pregnancy diagnoses were performed by transrectal ultrasonography (Mindray - 2200VET DP; Shenzhen Mindray Bio-Medical Electronics CO., Shenzhen, China) by detection of an embryo on day 31 , or a fetus on day 66 of gestation. The P/ET was calculated by dividing the number of pregnant cows on day 31 or day 66 by the number of cows that received an embryo on day 7 by timedembryo transfer. Pregnancy loss was calculated by dividing the number of cows that lost their pregnancy between days 31 and 66 by the number of pregnant cows on day 31 .

\subsection{Statistical analysis}

The binomial variables P/ET (days 31 and 66 of gestation) and pregnancy loss were analyzed by logistic regression using the glimmix procedure of SAS (SAS Institute Inc., Cary, NC; [31]). The model included the effects of the initial group of bacteria, SCC, days in milk, parity, milk production and interactions. Two contrasts were evaluated. The first contrast (C1) compared: control vs. presence of agents $\left(\mathrm{EV}+, \mathrm{EV}-\right.$, and $\left.\mathrm{C}_{+}\right)$, while the second contrast (C2) compared the presence of environmental agents (EV+ and EV) vs. presence of contagious agents $\left(\mathrm{C}_{+}\right)$. The second evaluation regarding the group of bacteria were Major agents vs. Minor agents. Results were considered significantly different if $\mathrm{P} \leq .05$ and a tendency if $0.05 \leq \mathrm{P} \leq .10$. Significant effects were reported by least squares means. The non-significant variables were excluded from the model according to the Wald's criterion $(\mathrm{P}>.20)$.

\section{Results}

No differences were detected in milk production, days in milk, service number and parity between SCC and type of intramammary infection bacteria groups (Table 1). The overall prevalence of intramammary infection in milk samples was 55.9\% (Table 2). Considering only the samples with positive culture, the agents most frequently isolated were CNS (32.8\%), Corynebacterium bovis (16.2\%), Streptococcus agalactiae (12.6\%), Escherichia coli (11.7) and Klebsiella spp. (8.8\%).

The CNS positive cows was grouped with the Control cows for the statistical analysis. This was done because CNS positive and Control cows had similar P/ET (42.2\% [109/258] vs. 42.2\% [258/ 611]).

Cows with positive bacterial growth had reduced $\mathrm{P} / \mathrm{ET}(\mathrm{P}<.01)$ at both 31 and at 66 days of gestation compared with the Control group (Table 3 ). Cows with milk samples containing environmental
Table 1

Number of animals and previous milk yield, days in milk, number of services and parturition by group of bacteria.

\begin{tabular}{|c|c|c|c|c|}
\hline \multirow[t]{2}{*}{ Item } & \multicolumn{4}{|l|}{ Group $^{a}$} \\
\hline & Control & $\mathrm{EV}+$ & EV- & $\mathrm{CT}+$ \\
\hline Cows, n & 869 & 82 & 201 & 245 \\
\hline Milk (kg/day) & $19.4 \pm 0.4$ & $19.3 \pm 0.9$ & $19.1 \pm 0.7$ & $18.7 \pm 0.6$ \\
\hline Days in milk & $122.7 \pm 3.5$ & $118.5 \pm 11.6$ & $136.6 \pm 7.3$ & $130.4 \pm 3.5$ \\
\hline Services $(n)^{c}$ & $1.8 \pm 0.1$ & $1.7 \pm 0.3$ & $2.0 \pm 0.2$ & $2.1 \pm 0.2$ \\
\hline Parity & $2.2 \pm 0.1$ & $2.4 \pm 0.2$ & $2.5 \pm 0.1$ & $2.4 \pm 0.1$ \\
\hline
\end{tabular}

a Control: No bacteria detected. EV+: Presence of gram positive environmental bacteria. EV-Presence of gram-negative environmental bacteria. CT+: Presence of contagious gram positive bacteria.

b Average of days in lactation on the day of embryo transfer.

c Number of services (ET).

agents, regardless if classified gram-positive or gram-negative, had reduced P/ET at 31 and 66 days of gestation, whereas cows with milk samples containing contagious gram-positive agents had only a tendency $(\mathrm{P}=.09)$ to decrease $\mathrm{P} / \mathrm{ET}$ at 31 days of gestation compared with Control. There was no effect of bacterial isolation in milk on pregnancy loss between 31 and 66 days (Table 3). Cows detected with isolation of environmental agents in milk had a tendency $(\mathrm{P}=.08)$ to reduce $\mathrm{P} / \mathrm{ET}$ on day 66 of gestation compared with cows detected with contagious infectious agents (Table 3 ).

Cows diagnosed with Major agents in the bacterial milk culture had reduced P/ET at both pregnancy diagnoses compared with cows classified in the Minor agents group. No difference on P/ET was found between cows diagnosed with Minor agents and Control groups (Table 4). Cows with SCC $>400,000$ cells $/ \mathrm{mL}$ had lower P/ET at 31 and 66 days of gestation than cows with SCC $<200,000$ cells/ $\mathrm{mL}$. Cows in the intermediary group (SCC between 200,000 and 400,000 cells $/ \mathrm{mL}$ ) had similar P/TE compared with the other two groups. There was no effect of SCC class on pregnancy loss (Table 5).

\section{Discussion}

This study evaluated the effects of udder health on P/ET at day 31 and 66 of gestation in recipient lactating dairy cows. The use of timed-embryo transfer was important to remove the effects of udder health before day 7 of gestation (ovarian follicle, oocyte, fertilization and early embryonic development). The use of a large number of animals $(n=1397)$ with collection of milk samples, for SCC and microbiological evaluation of milk samples, close to the timing of timed-embryo transfer allowed to group SCC and intramammary infection into different classes. In turn, it permitted a 
Table 2

Prevalence of mastitis-causing pathogens.

\begin{tabular}{|c|c|c|c|}
\hline Microorganism & Total $(\mathrm{n})$ & Total (\%) & Positive Culture (\%) \\
\hline Total Samples & 1397 & & \\
\hline Samples with negative culture & 611 & 43.3 & \\
\hline Samples with positive culture & 786 & 55.9 & \\
\hline Bacillus ssp. & 24 & 1.7 & 3.1 \\
\hline Citrobacter freundii & 3 & 0.2 & 0.4 \\
\hline Corynebacterium bovis & 127 & 9.0 & 16.2 \\
\hline Enterobacter spp. & 13 & 0.9 & 1.7 \\
\hline Enterococcus spp. & 14 & 1.0 & 1.8 \\
\hline Escherichia coli & 92 & 6.5 & 11.7 \\
\hline Klebsiella spp. & 69 & 4.9 & 8.8 \\
\hline Micrococcus spp. & 20 & 1.4 & 2.5 \\
\hline Pseudomonas spp. & 24 & 1.7 & 3.1 \\
\hline Coagulase Negative Staphylococcus spp. & 258 & 18.3 & 32.8 \\
\hline Staphylococcus aureus & 19 & 1.3 & 2.4 \\
\hline Streptococcus agalactiae & 99 & 7.0 & 12.6 \\
\hline Streptococcus bovis & 8 & 0.6 & 1.0 \\
\hline Streptococcus dysgalactiae & 7 & 0.5 & 0.9 \\
\hline Streptococcus uberis & 9 & 0.6 & 1.1 \\
\hline
\end{tabular}

Table 3

Effect of bacterial growth on pregnancy per embryo transfer [P/ET; \% (n/n)] and pregnancy loss $[\%(\mathrm{n} / \mathrm{n})]$ in dairy cows.

\begin{tabular}{llll}
\hline Item & P/ET at 31 days & P/ET at 66 days & Pregnancy loss \\
\hline Group $^{1}$ & & & \\
$\quad$ Control and CNS & $44.0(367 / 869)^{\mathrm{ax}}$ & $32.6(286 / 864)^{\mathrm{a}}$ & $20.6(81 / 367)$ \\
EV+ & $29.9(24 / 82)^{\mathrm{b}}$ & $18.1(17 / 82)^{\mathrm{b}}$ & $33.3(7 / 24)$ \\
EV- & $30.1(68 / 201)^{\mathrm{b}}$ & $19.6(52 / 197)^{\mathrm{b}}$ & $25.8(16 / 68)$ \\
C+ & $36.6(86 / 245)^{\mathrm{by}}$ & $28.1(69 / 243)^{\mathrm{ab}}$ & $17.0(17 / 86)$ \\
Contrast & & & \\
C1 & $\mathrm{P}<.01$ & $\mathrm{P}<.01$ & $\mathrm{P}=.35$ \\
C2 & $\mathrm{P}=.23$ & $\mathrm{P}=.08$ & $\mathrm{P}=.13$ \\
\hline
\end{tabular}

a, b Numbers in the column followed by distinct letters are different $(P<.01)$. ${ }^{x, y}$ Averages in the same row followed by distinct letters are different $(\mathrm{P}<.10){ }^{1}$ Control: Cows without isolation. CNS: Isolation of coagulase-negative staphylococci. $\mathrm{EV}+$ : Isolation of gram-positive environmental bacteria. EV-Isolation of gramnegative environmental bacteria. $\mathrm{C}+$ : Isolation of contagious gram-positive bacteria. $^{2} \mathrm{C} 1$ : control and CNS vs. isolation of agents (EV+, EV- and C+). C2: Isolation of environmental agents (EV+ and EV-) vs. Isolation of contagious agents $\left(C_{+}\right)$.

broader analysis of the subclinical infection types, as well as to evaluate pregnancy losses. According to McDermott et al. [32], the main objective of choosing a specific SCC threshold is to optimize the mastitis control program. The use of an appropriate threshold minimizes intramammary infection diagnostic errors and diminishes the propagation of agents within the herd [12]. In spite of the fact that categories of SCC were formed for P/ET analyses, a pilot study (unpublished) was conducted prior to the current experiment and found that the threshold of 100,000 cells/mL had greater sensitivity in detecting intramammary infection compared with the other thresholds, whereas the greatest specificity was observed with threshold at 400,000 cells $/ \mathrm{mL}$. In short, it is noteworthy to emphasize the need for strategies that include an aggressive
Table 5

Pregnancy per embryo transfer (P/ET) according to the somatic cell count (SCC) class.

\begin{tabular}{llll}
\hline Item & \multicolumn{4}{l}{ SCC categories (cells/mL) } \\
\cline { 2 - 4 } & $<200,000$ & $200,000-400,000$ & $>400,000$ \\
\hline P/ET, \% (n/n) & & & \\
At day 31 & $40.8(292 / 716)^{\mathrm{a}}$ & $37.3(50 / 134)^{\mathrm{ab}}$ & $30.4(75 / 247)^{\mathrm{b}}$ \\
At day 66 & $32.2(231 / 716)^{\mathrm{a}}$ & $27.6(37 / 134)^{\mathrm{ab}}$ & $24.7(61 / 247)^{\mathrm{b}}$ \\
Pregnancy Loss & $20.9(61 / 292)$ & $26.0(26 / 50)$ & $18.7(14 / 75)$ \\
\hline a-b Numbers in the same row followed by distinct letters are different $(\mathrm{P}<.01)$.
\end{tabular}

surveillance program that contains frequent milk collection for bacterial culture in addition to SCC to improve herd health and overall interpretation of intramammary infection on reproduction.

Several studies have shown deleterious effects of clinical as well as subclinical mastitis on the fertility of dairy cows $[3,5,16,17]$. In general, studies monitoring for subclinical mastitis were based solely on SCC [17,33,34]. However, in this study, subclinical mastitis was evaluated based on the isolation of the causative agents of the infection. The presence of mastitis-causing bacteria decreased the P/ET (Table 3). Some authors [4,23] state that disturbances in fertility of cows with mastitis are caused mainly by gram-negative bacteria, and that these disturbances could be influenced by lipopolysaccharide. On the contrary, this experiment clearly found the negative impact on P/ET is independent of the type of bacteria isolated, which agrees with previous studies using AI [3,5,15]. In those studies $[3,5,15]$, it was shown that both gram-positive and gram-negative bacteria negatively impacted the fertility during the late embryonic and early fetal stages of development. Cows diagnosed with Minor pathogens did not show reduced P/ET. Interestingly, cows diagnosed with Corynebacterium bovis had P/ET similar

Table 4

Effect of isolation of major or minor agents on pregnancy per embryo transfer $[\mathrm{P} / \mathrm{ET} ; \%(\mathrm{n} / \mathrm{n})]$ and pregnancy loss [\% (n/n)] in dairy cows.

\begin{tabular}{|c|c|c|c|c|}
\hline \multirow[t]{2}{*}{ Item } & \multicolumn{3}{|l|}{ Group $^{1}$} & \multirow[t]{2}{*}{ Contrast $^{2}$} \\
\hline & Control & Major & Minor & \\
\hline \multicolumn{5}{|l|}{$\mathrm{P} / \mathrm{ET}, \%(\mathrm{n} / \mathrm{n})$} \\
\hline At day 31 & $43.2(258 / 611)^{a}$ & $32.1(133 / 411)^{b}$ & $41.1(154 / 385)^{\mathrm{a}}$ & $\mathrm{P}=.03$ \\
\hline At day 66 & $33.5(200 / 607)^{a}$ & $24.4(102 / 396)^{\mathrm{b}}$ & $32.3(122 / 383)^{a}$ & $\mathrm{P}=.09$ \\
\hline Pregnancy loss & $20.2(54 / 258)$ & $19.1(26 / 133)$ & $18.2(30 / 154)$ & $\mathrm{P}=.42$ \\
\hline
\end{tabular}

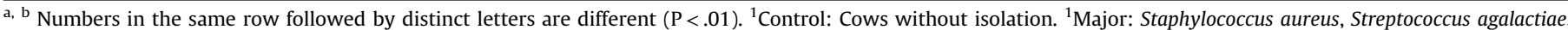

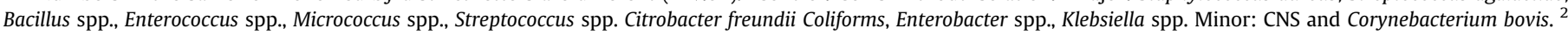
Contrast: control vs. isolation of agents (Major + Minor). 
to Major pathogens and lower than CNS (35.4\% vs. $42.2 \%)$, suggesting that Corynebacterium bovis is not a minor pathogen in regards to fertility and perhaps has a more specific influence in the early embryo and endometrium cross-communication. On the contrary, CNS-induced mastitis was indeed shown to be a Minor pathogen regarding P/ET. Nevertheless, it is important to note that it does not mean CNS, for example, do not induce any negative effects in reproduction tissues that could lead to sub-fertility in AI programs. Lavon et al. [34] have demonstrated that follicular functions, such as steroid synthesis, delayed ovulation, alteration of major steroidogenic gene expression, alteration of follicular dynamics and dominance could be altered and eventually associated with significant reductions in pregnancy per artificial insemination in subclinical mastitic cows infected by CNS.

The present study described that high SCC also had a negative impact on P/ET; cows that presented SCC $\geq 400,000$ cells/mL had a $\mathrm{P} / \mathrm{ET}$ reduced by $25.5 \%$. Hudson et al. [17] observed a reduction in reproductive performance of cows with an SCC $>399,000$ cells $/ \mathrm{mL}$. Similarly, Pinedo et al. [35] reported that cows with an SCC $>300,000$ cells $/ \mathrm{mL}$ before artificial insemination had a $44 \%$ lower risk of becoming pregnant than cows with an SCC $<300,000$ cells $/ \mathrm{mL}$. It is important to mention that most studies discussed herein are based on AI programs. In spite of the agreements on fertility outcomes, the same cannot be suggested on the mechanistic effects.

The mechanisms by which mastitis affect reproductive performance are not yet fully known, especially in its subclinical form. Mastitis triggers the production of a number of pro-inflammatory bioactive molecules (IL-1 $\beta$, IL- 8 , TNF $\alpha$, lipopolysaccharide, nitric oxide and prostaglandin $F 2 \alpha$ ) that can potentially harm the reproductive tract tissues and the embryo [4]. The release of such molecules is triggered in response to the inflammation in the mammary gland, but little can be determined as far as the exact site where these molecules have been synthesized [4]. This explains the fact that even without clinical signs of inflammation in the mammary gland, inflammatory agents may be involved in the fertility decline processes.

Soto et al. [23] suggested that cows with mastitis have lower fertility due to disturbances in oocyte development, cleavage and embryonic development into the blastocyst stage. Lower estrous expression [21], lack of ovulation [20,36], follicular growth interruption [37], and lower LH pulsatility and reduced production of $17 \beta$ estradiol [20] are all potential factors that decreased the fertility of cows with mastitis. In the present study, we used seven day old embryos as the starting point (blastocyst stage and presence of a corpus luteum in the recipient), which eliminates or at least partly rule out several of these ovarian and early embryonic associated factors previously found to decrease overall fertility. A further hypothesis for the reduced fertility is the involvement of inflammatory mediators in the adhesion and implantation processes. One factor possibly involved in the associated reduction in fertility is nitric oxide [23]. This molecule has been found to be active in physiological processes such as embryonic implantation and inflammation [38]. This radical can block embryonic development by apoptosis activation [23].

Lastly, the presence of agents in the mammary gland can possibly trigger the inflammatory cascade and consequently increase in systemic prostaglandin F2 $\alpha$ which could, by lysis of the CL, impedes the maintenance of gestation. This cascade could be initiated in response by either lipopolysaccharide release from gram-negative bacteria membranes [4] or by lipoteichoic acid or teichoic acid by gram-positive bacteria. Both molecules could affect fertility in a similar manner; an infusion of teichoic acid was able to induce abortion in female mice [39]. Although the current study did not find an effect of mastitis on pregnancy loss, a recent systematic review of epidemiologic studies [40], found that pregnancy loss (after first pregnancy diagnosis) can indeed be caused by mastitis events, particularly in cows with lower body condition score. However, several authors also found inconclusive results in many of the articles reviewed and the need for studies to prove the effect of clinical versus subclinical mastitis, timing of diagnosis and lactation number on pregnancy loss are warranted.

\section{Conclusion}

Cows with bacterial growth in milk samples collected close to embryo transfer had reduced P/ET at both 31 and 66 days of gestation. The $\mathrm{P} / \mathrm{ET}$ was reduced at 31 days of gestation regardless of the pathogen group compared with healthy cows, but cows in the Major pathogenicity group had an even further reduction in $\mathrm{P} /$ ET. Following a similar pattern, cows with SCC $>400,000$ cells $/ \mathrm{mL}$ had lower P/ET than animals with SCC $<200,000$ cells/mL at both 31 and 66 days of gestation. Pregnancy loss, on the other hand, was not different between bacterial isolates and SCC categories. In summary, elevated SCC significantly reduced P/ET, whereas environmental agents and those with Major pathogenicity yielded the greatest reduction in P/ET. The current study improves the notion that several agents, regardless on how the isolated bacteria from milk was grouped, negatively influence fertility. Moreover, these subclinical infections likely have a prominent effect on the uterine environment and its ability to maintain pregnancy during the early and late embryonic stages of development.

\section{Acknowledgments}

The authors would like to thank the support and all personnel involved from Fazenda Santa Luzia (Passos, Brazil), Vidavet Laboratorios (Botucatu, Brazil), Zoetis Animal Health and Conapec Jr. (Sao Paulo State University, Botucatu Brazil). We would like to extend our appreciation to CNPq (Brasilia, Brasil), which supported Lucas Barbosa supported with a graduate student scholarship.

\section{References}

[1] Harris BL, Kolver ES. Review of holsteinization on intensive pastoral dairy farming in New Zealand. J Dairy Sci 2001;84(Suppl.1):E-56-E61.

[2] Lucy MC. Mechanisms linking nutrition and reproduction in postpartum cows. Reprod Suppl 2003;61:415-27.

[3] Schrick FN, Hockett ME, Saxton AM, Lewis MJ, Dowlen HH, Oliver SP. Influence of subclinical mastitis during early lactation on reproductive parameters. J Dairy Sci 2001;84:1407-12. https://doi.org/10.3168/jds.S0022-0302(01) 70172-5

[4] Hansen PJ, Soto P, Natzke RP. Mastitis and fertility in cattle - possible involvement of inflammation or immune activation in embryonic mortality. Am J Reprod Immunol 2004;51:294-301. https://doi.org/10.1111/j.16000897.2004.00160.x.

[5] Santos JEP, Cerri RLA, Ballou MA, Higginbotham GE, Kirk JH. Effect of timing of first clinical mastitis occurrence on lactational and reproductive performance of Holstein dairy cows. Anim Reprod Sci 2004;80:31-45. https://doi.org/ 10.1016/S0378-4320(03)00133-7.

[6] Pereira MHC, Cooke RF, Alfieri AA, Vasconcelos JLM. Effects of vaccination against reproductive diseases on reproductive performance of lactating dairy cows submitted to AI. Anim Reprod Sci 2013;137:156-62. https://doi.org/ 10.1016/j.anireprosci.2012.12.011.

[7] Goldberg JJ, Wildman EE, Pankey JW, Kunkel JR, Howard DB, Murphy BM. The influence of intensively managed rotational grazing, traditional continuous grazing, and confinement housing on bulk tank milk quality and udder health. J Dairy Sci 1992;75:96-104. https://doi.org/10.3168/jds.S0022-0302(92) 77743-1.

[8] Kaneene JB, Miller R. Epidemiological study of metritis in Michigan dairy cattle. Vet Res 1994;25:253-7.

[9] LeBlanc SJ, Duffield TF, Leslie KE, Bateman KG, Keefe GP, Walton JS, et al. Defining and diagnosing postpartum clinical endometritis and its impact on reproductive performance in dairy cows. J Dairy Sci 2002;85:2223-36. https://doi.org/10.3168/jds.S0022-0302(02)74302-6.

[10] Bradley AJ, Leach KA, Breen JE, Green LE, Green MJ. Survey of the incidence and aetiology of mastitis on dairy farms in England and Wales. Vet Rec 2007;160:253-7. https://doi.org/10.1136/vr.160.8.253. 
[11] Smith KL, Hogan JS. The world of mastitis. In: Proc 2nd Inter'l symp. Mastitis milk qual; 2001. p. 1.

[12] Malek dos Reis CB, Barreiro JR, Moreno JFG, Porcionato MAF, Santos MV. Evaluation of somatic cell count thresholds to detect subclinical mastitis in Gyr cows. J Dairy Sci 2011;94:4406-12. https://doi.org/10.3168/jds.20103776.

[13] Dohoo IR, Smith J, Andersen S, Kelton DF, Godden S. Diagnosing intramammary infections: evaluation of definitions based on a single milk sample. J Dairy Sci 2011;94:250-61. https://doi.org/10.3168/jds.2010-3559.

[14] Schukken YN, Wilson DJ, Welcome F, Garrison-Tikofsky L, Gonzalez RN. Monitoring udder health and milk quality using somatic cell counts. Vet Res 2003;34:579-96. https://doi.org/10.1051/vetres.

[15] Barker AR, Schrick FN, Lewis MJ, Dowlen HH, Oliver SP. Influence of clinical mastitis during early lactation on reproductive performance of Jersey cows. J Dairy Sci 1998;81:1285-90. https://doi.org/10.3168/jds.S0022-0302(98) 75690-5.

[16] Hertl JA, Gröhn YT, Leach JDG, Bar D, Bennett GJ, González RN, et al. Effects of clinical mastitis caused by gram-positive and gram-negative bacteria and other organisms on the probability of conception in New York State Holstein dairy cows. J Dairy Sci 2010;93:1551-60. https://doi.org/10.3168/jds.20092599.

[17] Hudson CD, Bradley AJ, Breen JE, Green MJ. Associations between udder health and reproductive performance in United Kingdom dairy cows. J Dairy Sci 2012;95:3683-97. https://doi.org/10.3168/jds.2011-4629.

[18] Moore DA, Overton MW, Chebel RC, Truscott ML, BonDurant RH. Evaluation of factors that affect embryonic loss in dairy cattle. J Am Vet Med Assoc 2005;226:1112-8. https://doi.org/10.2460/javma.2005.226.1112.

[19] Philpot WN, Nickerson SC. Mastitis: counter attack. Naperville: Babson Bros; 1991. p. 150.

[20] Hockett ME, Almeida RA, Rohrbach NR, Oliver SP, Dowlen HH, Schrick FN Effects of induced clinical mastitis during preovulation on endocrine and follicular function. J Dairy Sci 2005;88:2422-31. https://doi.org/10.3168/ jds.S0022-0302(05)72920-9.

[21] Hockett ME, Hopkins FM, Lewis MJ, Saxton AM, Dowlen HH, Oliver SP, et al. Endocrine profiles of dairy cows following experimentally induced clinical mastitis during early lactation. Anim Reprod Sci 2000;58:241-51. https:/| doi.org/10.1016/S0378-4320(99)00089-5.

[22] Putney DJ, Mullins S, Thatcher WW, Drost M, Gross TS. Embryonic development in superovulated dairy cattle exposed to elevated ambient temperatures between the onset of estrus and insemination. Anim Reprod Sci 1989;19: 37-51. https://doi.org/10.1016/0378-4320(89)90045-6.

[23] Soto P, Natzke RP, Hansen PJ. Identification of possible mediators of embryonic mortality caused by mastitis: actions of lipopolysaccharide, prostaglandin F2 $\alpha$, and the nitric oxide generator, sodium nitroprusside dihydrate, on oocyte maturation and embryonic development in cattle. Am J Reprod Immunol 2003;50:263-72. https://doi.org/10.1034/j.16000897.2003.00085.x.

[24] Ealy AD, Drost M, Hansen PJ. Developmental changes in embryonic resistance to adverse effects of maternal heat stress in cows. J Dairy Sci 1993;76: 2899-905. https://doi.org/10.3168/jds.S0022-0302(93)77629-8.

[25] Demetrio DGB, Santos RM, Demetrio CGB, Vasconcelos JLM. Factors affecting conception rates following artificial insemination or embryo transfer in lactating Holstein cows. J Dairy Sci 2007;90:5073-82. https://doi.org/ 10.3168/jds.2007-0223.

[26] National Research Council. Nutrient requirements of dairy cattle. seventh ed. Washington: Natl. Acad. Press; 2011.

[27] Mapletoft RJ. IVIS reviews in veterinary medicine. Ithaca: International Veterinary Information Service; 2006.

[28] Pereira MHC, Sanches CP, Guida TG, Rodrigues ADP, Aragon FL, Veras MB, et al Timing of prostaglandin F2 $\alpha$ treatment in an estrogen-based protocol for timed artificial insemination or timed embryo transfer in lactating dairy cows. J Dairy Sci 2013;96:2837-46. https://doi.org/10.3168/jds.2012-5840.

[29] Quinn PJ, Markey BK, Carter ME, Donelly WJ, Leonard FC. Microbiologia Veterinaria e Doenças Infecciosas. Porto Alegre: Artmed; 2005.

[30] Schepers AJ, Lam TJGM, Schukken YH, Wilmink JBM, Hanekamp WJA. Estimation of variance components for somatic cell counts to determine thresholds for uninfected quarters. J Dairy Sci 1997;80:1833-40. https://doi.org 10.3168/jds.S0022-0302(97)76118-6.

[31] SAS. SAS/STAT ${ }^{\mathbb{B}}$ User's guide (Release 8.2). Cary. SAS Inst. Inc.; 2001.

[32] McDermott MP, Erb HN, Natzke RP. Predictability by somatic cell counts related to prevalence of intrammary infection within herds. J Dairy Sci 1982;65:1535-9. https://doi.org/10.3168/jds.S0022-0302(82)82378-3.

[33] Pinedo PJ, Melendez P, Villagomez-Cortes JA, Risco CA. Effect of high somatic cell counts on reproductive performance of Chilean dairy cattle. J Dairy Sci 2009;92:1575-80. https://doi.org/10.3168/jds.2008-1783.

[34] Lavon Y, Ezra E, Leitner G, Wolfenson D. Association of conception rate with pattern and level of somatic cell count elevation relative to time of insemination in dairy cows. J Dairy Sci 2011;94:4538-45. https://doi.org/10.3168/ jds.2011-4293.

[35] Pinedo P, Risco C, Melendez P. A retrospective study on the association between different lengths of the dry period and subclinical mastitis, milk yield, reproductive performance, and culling in Chilean dairy cows. J Dairy Sci 2011;94:106-15. https://doi.org/10.3168/jds.2010-3141.

[36] Williams EJ, Sibley K, Miller AN, Lane EA, Fishwick J, Nash DM, et al. The effect of escherichia coli lipopolysaccharide and tumour necrosis factor alpha on ovarian function. Am J Reprod Immunol 2008;60:462-73. https://doi.org/ 10.1111/j.1600-0897.2008.00645.x.

[37] Herath S, Williams EJ, Lilly ST, Gilbert RO, Dobson H, Bryant CE, et al. Ovarian follicular cells have innate immune capabilities that modulate their endocrine function. Reproduction 2007;134:683-93. https://doi.org/10.1530/REP-070229.

[38] Lima-Verde IB, Bruno JB, Matos MHT, Rodrigues APR, Figueiredo JR Oliveira MAL, et al. Implicações do estresse oxidativo no ovário e no embrião mamífero. Med Veterinária Recife 2007;1:81-8.

[39] Kajikawa S, Kaga N, Futamura Y, Kakinuma C, Shibutani Y. Lipoteichoic acid induces preterm delivery in mice. J Pharmacol Toxicol Meth 1998;39:147-54. https://doi.org/10.1016/S1056-8719(98)00015-X.

[40] Dahl MO, Maunsell FP, De Vries A, Galvao KN, Risco CA, Hernandez JA. Evidence that mastitis can cause pregnancy loss in dairy cows: a systematic review of observational studies. J Dairy Sci 2017;100:8322-9. https://doi.org/ $10.3168 /$ jds.2017-12711. 